\title{
Antimicrobial activity of tropical soft corals found in the Northern Straits of Malacca
}

Running title: Antimicrobial activity of tropical soft corals

\author{
${ }^{1}$ Hana Marican, ${ }^{4}$ Raihana Edros $*, 1,3$ Mahadi Mohammad, ${ }^{2}$ Sazlina Salleh \\ ${ }^{1}$ School of Biological Sciences, Universiti Sains Malaysia, Penang, 11800, Malaysia \\ ${ }^{2}$ Centre for Policy Research, Universiti Sains Malaysia, Penang, 11800, Malaysia \\ ${ }^{3}$ Centre of Marine and Coastal Studies, Universiti Sains Malaysia, Penang 11800, Malaysia \\ ${ }^{4}$ Faculty of Technology, Universiti Pahang Malaysia, Gambang, Pahang 26300, Malaysia \\ Corresponding author: rzahirah@ump.edu.my
}

\begin{abstract}
The study was conducted to obtain and test crude extracts from soft corals found at Pulau Payar, an island off the northern Straits of Malacca. Specimens were extracted in an equal volume of methanol and dichloromethane. The samples were then concentrated to obtain crude extracts. Anti-bacterial activities of the crude extracts were tested by disc diffusion method, minimum inhibition concentration (MIC) and minimum bacterial activities (MBC) assays. Out of twelve crude extracts tested, 50 percent of them showed inhibition for Staphylococcus aureus and MRSA; and approximately 8 percent have showed inhibition for Enterococcus raffinosus. The MIC of each extract is stated in the tables below. Only one of them showed bactericidal properties against MRSA. Soft corals around the world, have been found to contain beneficial chemical compounds, however not much research has been done in the region. This shows that soft coral extracts found in the Northern Straits of Malacca do have antibacterial potential, and this potential can be harnessed for future pharmaceutical exploration.
\end{abstract}

Keywords: Antibacterial, octocoral, secondary metabolites, ESKAPE, extract, Malaysia, disc diffusion, MIC, MBC

Abbreviation: ESKAPE- Enterococcus raffinosus, Staphylococcus aureus, Klebsilla pneunomiae, Acinobacter baumanii, Pseudomonas aeruginosa, Enterobacter aerogenes

MRSA- Methicillin-resistant Staphylococcus aureus

MIC- Minimum inhibition concentration, MBC- Minimum bactericidal concentration 


\section{INTRODUCTION}

Ever since the 1960s, there has been a growing need for drugs to control new illnesses and to combat resistant strains of microorganisms. This has encouraged the search for new sources of natural products. Marine environments are one of the richest and most complex ecosystems in terms of biological and chemical diversity [1]. In 2012, approximately 1241 new biochemical compounds were reported, which clearly identifies the marine environment as a bountiful source of bioactive compounds [2,3,4]. Bioactive natural products have been isolated from both marine macro- and micro-organisms. The advances of science and technology in the past 50 years, have resulted in the isolation of approximately 24,662 unique new bioactive compounds from marine organisms [5]. Out of this, marine invertebrates are known to be major producers of these natural products which serve several biological and ecological roles [6].

Antimicrobial activity of secondary metabolites has been reported extensively for several groups of marine invertebrates, such as ascidians [7], byrozoans [8], sponges [9.10], hard corals [11], gorgonian octocorals [12] and alcyonacean soft corals [13]. Bioactive secondary metabolites from marine organism can be divided into several groups; steroids, terpenoids, isoprenoids, nonisoprenoids, quinones, brominated compounds, nitrogen heterocyclics and nitrogen sulphur heterocyclics $[14,4]$.

Soft corals such as Coelenterates (class: Anthozoa, subclass: Octocorallia) have been studied and are known to produce a range of valuable compounds [15]. Most of these compounds are categorised to be sesquiterpenoids and diterpenoids [4].These compounds have a direct use for the octocorals. For example, 3 extracts of Sinularia species displayed defence mechanism against predators [16]. Soft coral extracts have also been discovered to aid in interspecific competition for space $[17,18]$ and in prevention of fouling on the coral tissue [19]. In addition, a range of secondary metabolites play an important role solely in reproduction of soft corals. Diterpenes such as thunbergol and epithunbergol, are present in the eggs of Lobophytum compactum and Lobophytum crissum, but do not appear to be effective in deterring reef fish, and they do not possess effective antibacterial properties [20,21]. Besides benefitting the corals themselves, secondary metabolites are known to have properties that are beneficial to humans such as antifungal, antiviral and antibacterial activities [5,22].

Soft corals around the world, have been found to contain beneficial chemical compounds, however not much research has been done in the region. This is a cause for concern as coral reefs in Southeast Asia have the highest degree of biodiversity and most extensive coastlines worldwide. Total coral reef area is almost $100,000 \mathrm{~km}^{2}$, covering nearly 34 percent of the world's total coral reef area [23]. Southeast Asian coral reefs hold more than 75 percent of the global coral species (over 600 of the world's nearly 800 reef-building coral species) and more than 33 percent of the global reef fish [23]. Thus, a fundamental study on the coral reefs; not only ecology, but also taxonomy, and other biochemical studies are necessary for exploration. Most researches have been conducted on the temperate species, therefore we have sought to study whether there is a similarity between the secondary metabolites of temperate climate and those are found in our region; and if climate (mainly sea surface temperature) might play a role in the physiology of the soft corals.

Little is known on the antimicrobial activity of octocorals in this region, and this is surprising considering our location in the coral triangle. Therefore, the aim of the current study was to test the antimicrobial activity of crude extracts of various soft coral species from the northern Straits of Malacca, more specifically, Pulau Payar and Pulau Songsong against a range of clinical strains of bacteria. 


\section{METHODOLOGY}

\subsection{Collection}

Samples were collected by SCUBA from Pulau Payar Marine Park, and Pulau Songsong, two islands off the coast of Kedah, Malaysia. The average sea surface temperature of the two islands was $32^{\circ} \mathrm{C}$. Specimens were collected as they were readily available in the study area. Whole specimens were collected between depths of $5 \mathrm{~m}$ and $20 \mathrm{~m}$, and frozen at $20^{\circ} \mathrm{C}$ for further analysis.

\subsection{Extraction}

Samples were defrosted and weighed to $100 \mathrm{~g}$. Samples were macerated and extracted in 1:1 ratio of $90 \%$ methanol and dichloromethane for 24 to 48 hours. Extracts were then filtered using a vacuum filter and $0.45 \mu \mathrm{m}$ filter membrane. Filtrate was concentrated in a rotary evaporator. Crude extracts were stored at $-20^{\circ} \mathrm{C}$ to prevent the degradation of secondary metabolites.

\subsection{Antimicrobial Assays}

Disk diffusion, minimum inhibition concentration (MIC) and minimum bactericidal concentration (MBC) tests were performed on twelve soft coral crude extracts. Tests were conducted based on the Clinical Laboratory Standard Institute (CLSI) protocols for antimicrobial assays. Tests were done in duplicates, and repeated twice. Mueller Hinton agar (MHA) and Mueller Hinton broth (MHB) were prepared for the tests. Bacteria used were the 'ESKAPE' strains which consist of Enterococcus raffinosus ATCC 49464, Staphylococcus aureus ATCC 25923, Klebsilla pneunomiae, Acinobacter baumanii, Pseudomonas aeruginosa ATCC 27853 and Enterobacter aerogenes ATCC 51697, as well as Methicillinresistant Staphylococcus aureus (MRSA). E. raffinosus, S. aureus and MRSA are grampositive bacteria, while $K$. pneunomiae, A. baumanii, $P$. aeruginosa and E. aerogenes are gram-negative bacteria. All tests were done in a Biosafety Cabinet Esco class II type A2, and incubation was done in lab companion incubator.

Extracts which had inhibition zones on the disc diffusion assays, were then tested to find the minimum inhibition concentration (MIC). Wells that showed positive results for MIC were plated to find out if the extracted was bactericidal or bacteriostatic (MBC test).

\subsubsection{Disc Diffusion test}

3 to 5 well-isolated colonies were selected from the MHA plate culture and transferred into a universal tube containing $4 \mathrm{~mL}$ of sterilised MHB. The inoculated broths were incubated at $37^{\circ} \mathrm{C}$ for 18 to 24 hours. The inoculum was then prepared by adjusting the turbidity of growth culture with sterile broth to achieve $0.5 \mathrm{OD}$ at $625 \mathrm{~nm}$; which means that the suspension contained approximately 1 to $2 \times 10^{8} \mathrm{CFU} / \mathrm{mL}$. Test plates were inoculated by dipping sterile swab into the adjusted suspension and streaking the swab over the entire dried surface area of MHA plates. The concentration of crude extracts used for disc diffusion was set at $4 \mathrm{mg} / \mathrm{mL}$. $6 \mathrm{~mm}$ discs were prepared with the crude extracts, and placed on MHA plates inoculated with the respective bacteria strains. Plates were then incubated at $37^{\circ} \mathrm{C}$ for $18-24$ hours. The inhibition zones were measured to the nearest whole millimetre.

\subsubsection{Minimum inhibition concentration (MIC) test}


MIC tests were done in 96-well plates. $50 \mu \mathrm{L}$ of sterile MHB was aliquoted into all wells, except that of the $1^{\text {st }}$ row where $90 \mu \mathrm{L}$ of sterile MHB was added. $10 \mu \mathrm{L}$ of extract $(400 \mathrm{mg} / \mathrm{mL}$ concentration) was added into the $1^{\text {st }}$ row well and mixed thoroughly. Subsequently, $50 \mu \mathrm{L}$ from the $1^{\text {st }}$ row wells were added into the $2^{\text {nd }}$ row wells and mixed well by pipetting. This continued up until the $12^{\text {th }}$ row of wells, where a final $50 \mu \mathrm{L}$ of mixture was discarded. $50 \mu \mathrm{L}$ of bacteria $\left(1 \times 10^{6} \mathrm{CFU} / \mathrm{mL}\right)$ was added into the wells. This made the final concentrations in wells for the MIC test to be, starting from the $1^{\text {st }}$ well to $12^{\text {th }}$ well was a 2 fold dilution; with the concentrations being $20 \mathrm{mg} / \mathrm{mL}, 10 \mathrm{mg} / \mathrm{mL}, 5 \mathrm{mg} / \mathrm{mL}, \quad 2.5 \mathrm{mg} / \mathrm{mL}, \quad 1.25 \mathrm{mg} / \mathrm{mL}$, $0.625 \mathrm{mg} / \mathrm{mL}, \quad 0.3125 \mathrm{mg} / \mathrm{mL}, \quad 0.156 \mathrm{mg} / \mathrm{mL}, \quad 0.0781 \mathrm{mg} / \mathrm{mL}, \quad 0.039 \mathrm{mg} / \mathrm{mL}, \quad 0.0195 \mathrm{mg} / \mathrm{mL}$, $0.0098 \mathrm{mg} / \mathrm{mL}$ respectively. Each plate had positive and negative controls, where the positive controls were Ampicillin, Vancomycin and Polymycin B; and the negative control was sterile MHB. The concentration of positive control antibiotics (Ampicillin, Vancomycin and Polymycin B), also for the MIC test were $2 \mathrm{mg} / \mathrm{mL}, 1 \mathrm{mg} / \mathrm{mL}, 0.5 \mathrm{mg} / \mathrm{mL}, 0.25 \mathrm{mg} / \mathrm{mL}$, $\quad 0.125 \mathrm{mg} / \mathrm{mL}, \quad 0.0625 \mathrm{mg} / \mathrm{mL}, \quad 0.03125 \mathrm{mg} / \mathrm{mL}, \quad 0.0156 \mathrm{mg} / \mathrm{mL}, \quad 0.0078 \mathrm{mg} / \mathrm{mL} \quad$ and $0.0039 \mathrm{mg} / \mathrm{mL}$ respectively.

The 96 well plates were incubated at $37^{\circ} \mathrm{C}$ for $18-24$ hours. Wells in which there was no growth were considered to have inhibition, and the MIC was the well with the lowest concentration of no bacterial growth.

\subsubsection{Minimum bactericidal concentration $(M B C)$ test}

MBC tests were done on MHA plates. Each MHA plate was divided into 8 sections. $10 \mu \mathrm{L}$ was taken from each well that did not show growth in the MIC test and aliquoted on a section of MHA. Plates were left to dry for 3-5 minutes, and then incubated at $37^{\circ} \mathrm{C}$ for 18 to 24 hours. Sections were there was growth meant that the extracts were bacteriostatic (cell inhibition), while sections with no growth showed bactericidal (cell death) activity.

\section{RESULTS}

Antimicrobial assays were performed with extracts of 12 soft corals. The data revealed considerable variability in natural extract concentration and in antimicrobial activity as tabulated in Table 1. Out of 12 crude extracts tested, 6 showed inhibition for Staphylococcus aureus and MRSA; and 2 showed inhibition for Enterococcus raffinosus. Klebsilla pneunomiae, Acinobacter baumanii, Pseudomonas aeruginosa and Enterobacter aerogenes did not yield any positive inhibition zones in the disk diffusion tests. From the active soft coral species examined S3 exhibited the highest antimicrobial activity (Table 2).

\subsection{Antibacterial Screening}

Extracts from samples S1, S2, S3, S7, S8 and S13 showed inhibition in the disc diffusion tests against Staphylococcus aureus and MRSA. The extracts came from specimens Sarcophyton sp., Carijoa sp., Coelogorgia sp., Junceella sp. and Virgularia sp. respectively. Extracts from S2 and S3 showed inhibition against Enterococcus rafinosa. It is important to note that the extracts only exhibited resistance against gram-positive bacteria. 
INTERNATIONAL JOURNAL OF ENGINEERING TECHNOLOGY AND SCIENCES (IJETS) Vol.6 (1)

Dec 2016 DOI: http://dx.doi.org/10.15282/ijets.6.2016.1.1.1051

Table 1 depicting the disc diffusion inhibition zones of the crude extracts. Those left blank showed no inhibition activity against the bacteria tested

\begin{tabular}{|c|c|c|c|c|c|c|c|c|}
\hline & \multicolumn{8}{|c|}{ Disc diffusion inhibition zone (mm) } \\
\hline Specimen & Extracts & E.raffinosus & S.aureus & K.pneunomiae & A.baumanii & P.aeruginosa & E.aerogenes & MRSA \\
\hline $\begin{array}{l}\text { Sarcophyton } \\
\text { sp. }\end{array}$ & $\mathrm{S} 1$ & - & 9 & - & - & - & - & 7 \\
\hline Carijoa sp. & S2 & 8 & 10 & - & - & - & - & 12 \\
\hline $\begin{array}{l}\text { Coelogorgia } \\
s p \text {. }\end{array}$ & S3 & 9 & 11 & - & - & - & - & 11 \\
\hline Viminella sp. & S6 & - & - & - & - & - & - & - \\
\hline Junceella sp. & S7 & - & 12 & - & - & - & - & 8 \\
\hline Junceella sp. & S8 & - & 9 & - & - & - & - & 7 \\
\hline $\begin{array}{l}\text { Echinogorgia } \\
\text { sp. }\end{array}$ & S9 & - & - & - & - & - & - & - \\
\hline $\begin{array}{l}\text { Dendronepthea } \\
\text { sp. }\end{array}$ & S10 & - & - & - & - & - & - & - \\
\hline $\begin{array}{l}\text { Dendronepthea } \\
\text { sp. }\end{array}$ & S11 & - & - & - & - & - & - & - \\
\hline Ellisella $s p$. & $\mathrm{S} 12$ & - & - & - & - & - & - & - \\
\hline Virgularia sp. & S13 & - & 8 & - & - & - & - & 8 \\
\hline Melithaea sp. & S14 & - & - & - & - & - & - & - \\
\hline
\end{tabular}

Minimum inhibition concentration (MIC) and minimum bactericidal concentration (MBC)

The MIC and MBC of the positively screened extracts are depicted in table 2. S3 had the lowest MIC against $S$. aureus. Only extract $\mathrm{S} 1$ showed bactericidal properties against MRSA.

Table 2: depicting the MIC and MBC values of the crude extracts which exhibited positive results during the disc diffusion screening test

\begin{tabular}{|l|l|l|l|l|l|l|}
\hline & \multicolumn{3}{|c|}{$\begin{array}{c}\text { Minimum Inhibition Concentration (MIC) } \\
\text { in mg/mL }\end{array}$} & \multicolumn{3}{c|}{$\begin{array}{c}\text { Minimum Bactericidal Concentration } \\
\text { (MBC) in mg/mL }\end{array}$} \\
\hline Extracts & S. aureus & MRSA & E. raffinosus & S. aureus & MRSA & E. raffinosus \\
\hline S1 & 5 & 10 & & - & 10 & \\
\hline S2 & 10 & 20 & - & - & - & - \\
\hline S3 & 2.5 & 10 & - & - & - & - \\
\hline S7 & 20 & 20 & & - & - & \\
\hline S8 & 20 & - & & - & - & \\
\hline S13 & - & - & & - & - & \\
\hline
\end{tabular}



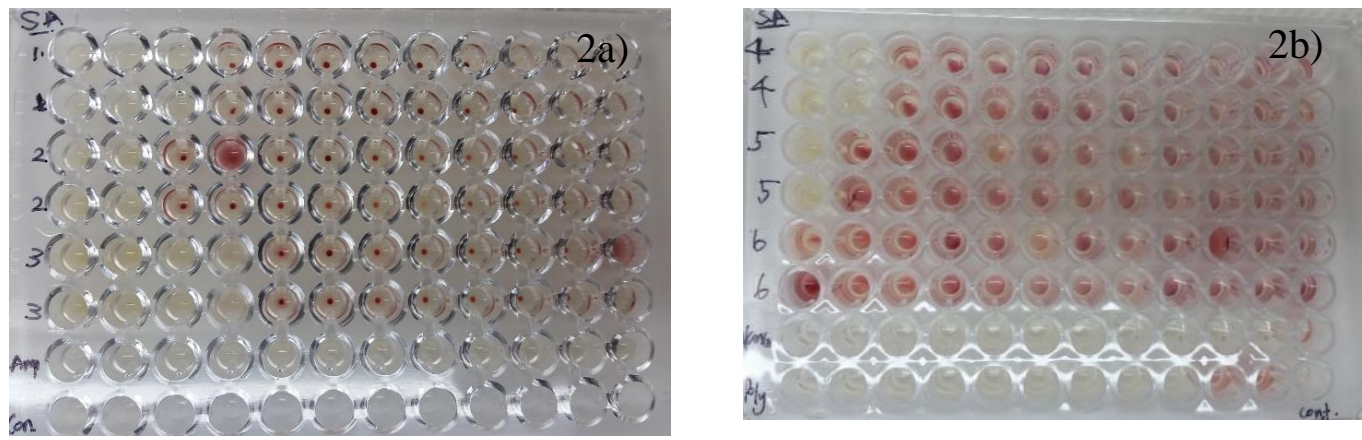

Figure 2a and b depicting MIC test results for Staphylococcus aureus, where wells containing bacteria are stained red with triphenyl-tetrazolim chloride solution (TTP).
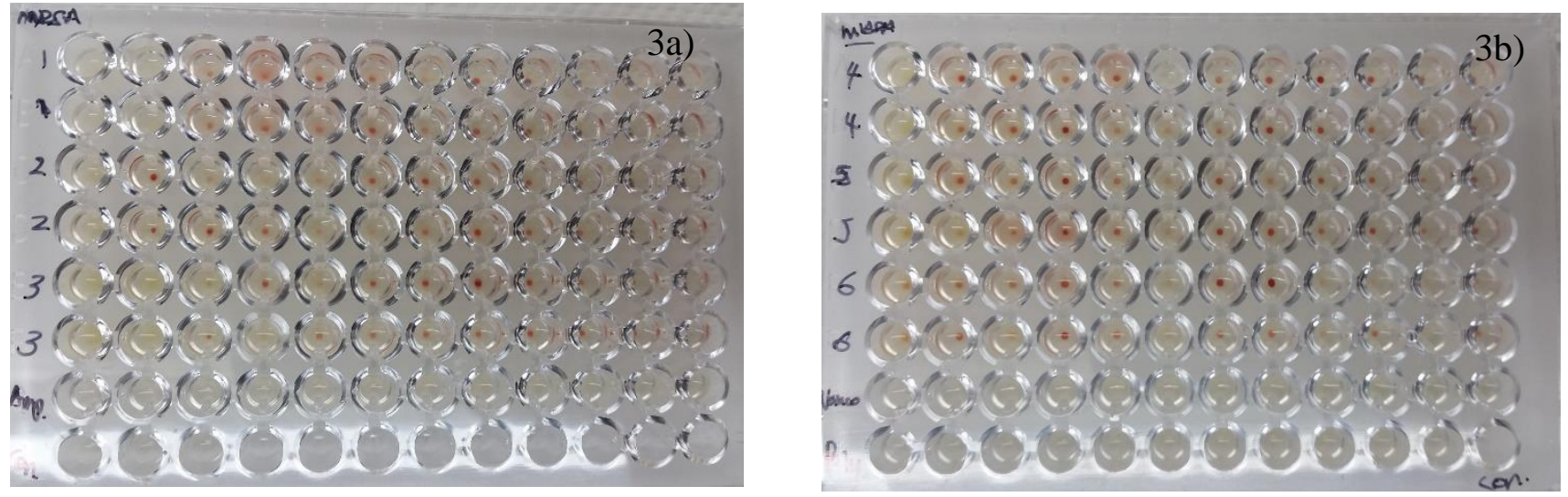

Figure 3a and b depicting MIC test results for MRSA, where wells containing bacteria are stained red with triphenyl-tetrazolim chloride solution (TTP).
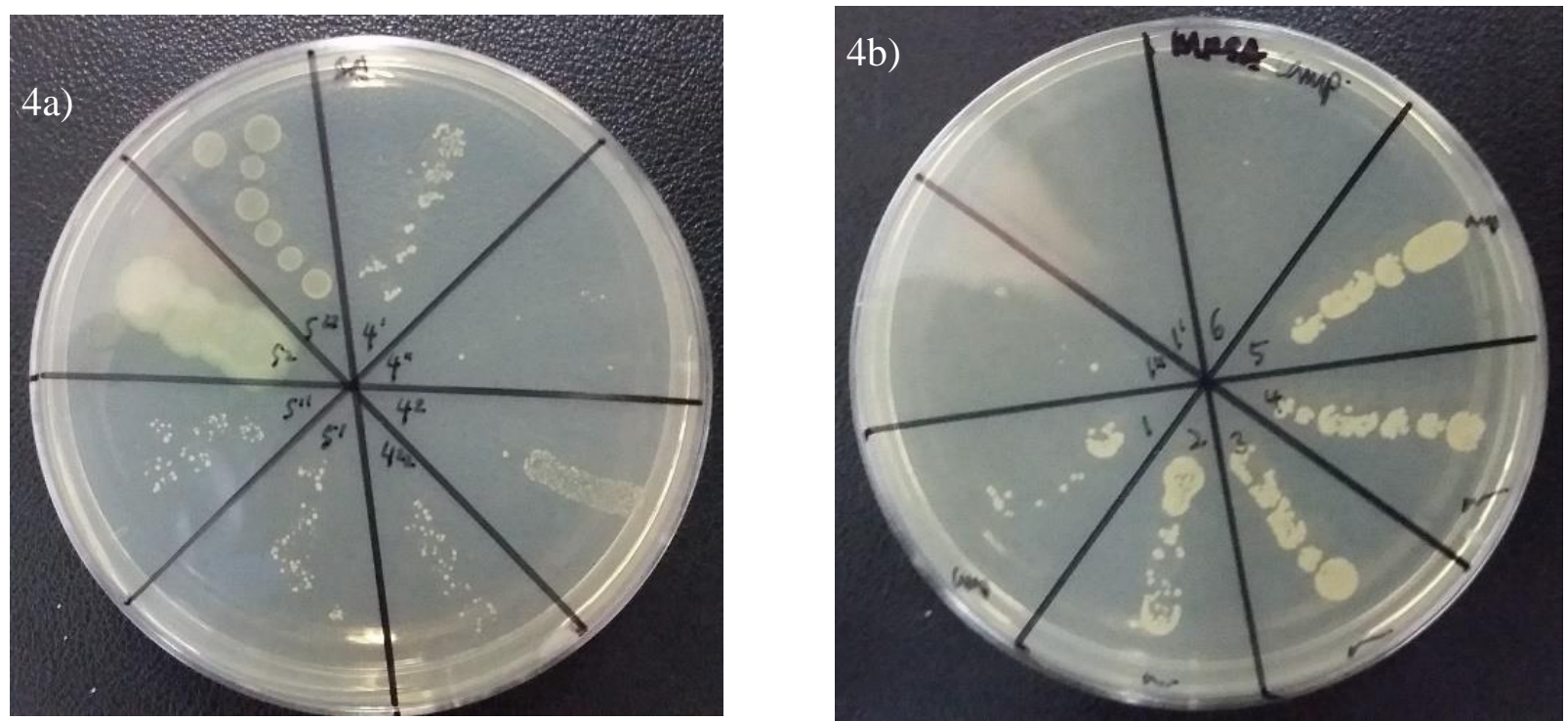

Figure $4 a$ and $b$ depicting $\mathrm{MBC}$ results. In figure $4 \mathrm{~b}$, section labelled $1^{1}$ and $1^{11}$ display bactericidal activity of the extract 


\section{DISCUSSION}

Due to the fact that a large proportion of marine bioactive metabolites with different biological activities are provided by marine organisms, the coral reef ecosystems have become sources of great interest to natural product discovery. The current study was conducted to screen the crude extracts of ten soft coral species collected from the coral reef ecosystems in the northern Straits of Malacca and test their potential to inhibit the growth of clinical bacteria strains.

Our results indicated that extracts from Sarcophyton sp., Carijoa sp., Coelogorgia sp., Junceella sp. and Virgularia $s p$. possessed antibacterial activity against the tested bacterial strains. Only gram positive bacteria were susceptible to the soft coral extracts. Gram negative bacteria have a unique outer membrane which excludes certain drugs and antibiotics from entering the cell [24]. Therefore, gram negative bacteria are more resistant.

In a study done on Sarcophyton trocheliophorum from the Red Sea [25,26], the extract was found to inhibit the same set of bacteria tested in the current study; where the ethyl acetate and hexane extracts were more effective against gram negative and gram postivite bacteria respectively. Sarcophyton is well known as a producer species of sarcophine derivatives [27,28]. Sarcophine was isolated from the $S$. glaucum collected from the Red Sea [29]. Approximately two hundred terpenes had been previously isolated from 16 species of the genus Sarcophyton demonstrating various biological features, such as antiviral, antifouling activities, predator deterrence, and anti-inflammatory activities [30]. In a study done in Indonesia on Lobophytum sp. (which is similar to genus Sarcophyton), it was found that crude fractions of the specimen had moderate anti-bacterial activity against test bacteria from both gram positive and gram negative bacteria [31]. Purified ethanolic extracts of Carijoa sp. from the Indo-pacific yielded 4 compounds in which displayed cytotoxic activity against human hepatoma Bel-7402 and human normal embryonic lung fibroblast MRC-5, as well as antibiotic resistance against a range of bacteria [32].

A study on Vietnamese octocorals by Kapustina et al. (2014)[33], found an extract from Junceella sp. exhibited antibacterial activity against Escherichia coli, but was inactive against Bacillus megaterium. This might have been due to the difference in cell wall, as E.coli is gram negative, and B. megaterium is gram positive. This is in contrast with the results of this study as Staphylococcus aureus is a gram positive bacteria. The extract also showed moderate toxicity against brine shrimp Artemia salina. More evidence to the antibacterial properties of Junceella sp. can be found in a study done in India [34], where the methanolic extract of Junceella juncea inhibited growth of bacterial strains such as Salmonella typhii and Vibrio cholera.

\section{CONCLUSION}

In conclusion, the soft corals of the northern Straits of Malacca potentially have medicinal value, more specifically that of antibacterial properties. This study provides evidence that there is indeed potential of soft corals in the area.

Future studies should include testing of different solvent extracts, as well as a wider range of bacteria. Other properties such as anti-cancer should also be tested, to study the effectiveness of the crude extracts. Purification of these extracts can be done to isolate the individual effective secondary metabolites.

\section{ACKNOWLEDGEMENTS}

We thank the staff and fellow researchers at the School of Biological Sciences, University Sains 
Malaysia; Novel Antibiotic Laboratory, Universiti Kebangsaan Malaysia; and Faculty of Engineering Technology, Universiti Malaysia Pahang. The corals used in this current study were collected under permission (permit number: JTLM 630-7(9)) of the Department of Marine Parks, Malaysia. This project was funded by USM-RUI Grant (1001.PBIOLOGI.811245) and UMP Grant RDU 140306. This manuscript is published as part of my masters' dissertation.

\section{REFERENCES}

[1]Haefner, B., 2003. Drugs from the deep: marine natural products as drug candidates. Drug discovery today, $8(12)$, pp.536-544.

[2]Blunt, J.W., Copp, B.R., Keyzers, R.A., Munro, M.H. and Prinsep, M.R., 2014. Marine natural products. Natural product reports, 31(2), pp.160-258.

[3]Martins, A., Vieira, H., Gaspar, H. and Santos, S., 2014. Marketed marine natural products in the pharmaceutical and cosmeceutical industries: Tips for success. Marine drugs, 12(2), pp.1066-1101.

[4]Datta, D., Talapatra, S.N. and Swarnakar, S., 2015. Bioactive compounds from marine invertebrates for potential medicines-an overview. International Letters of Natural Sciences, 7.

[5]Blunt, J.W., Copp, B.R., Keyzers, R.A., Munro, M.H. and Prinsep, M.R., 2015. Marine natural products. Nat. Prod. Rep, 32(2), pp.116-211.

[6]Sammarco, P.W. and Coll, J.C., 1988. The chemical ecology of alcyonarian corals. In Bioorganic marine chemistry (pp. 87-116). Springer Berlin Heidelberg.

[7]Wahl, M., Jensen, P.R. and Fenical, W., 1994. Chemical control of bacterial epibiosis on ascidians. Marine Ecology Progress Series, 110, pp.45-57.

[8]Walls, J.T., Ritz, D.A. and Blackman, A.J., 1993. Fouling, surface bacteria and antibacterial agents of four bryozoan species found in Tasmania, Australia. Journal of experimental marine biology and ecology, 169(1), pp.1-13.

[9]Burkholder, P.R. and Ruetzler, K., 1969. Antimicrobial activity of some marine sponges. Nature, 222(5197), pp.983-984.

[10]Becerro, M.A., Lopez, N.I., Turon, X. and Uriz, M.J., 1994. Antimicrobial activity and surface bacterial film in marine sponges. Journal of Experimental Marine Biology and Ecology, 179(2), pp.195-205.

[11]Koh, E.G., 1997. Do scleractinian corals engage in chemical warfare against microbes?. Journal of Chemical Ecology, 23(2), pp.379-398.

[12]Jensen, P.R., Harvell, C.D., Wirtz, K. and Fenical, W., 1996. Antimicrobial activity of extracts of Caribbean gorgonian corals. Marine Biology, 125(2), pp.411-419.

[13]Slattery, M., McClintock, J.B. and Heine, J.N., 1995. Chemical defenses in Antarctic soft corals: evidence for antifouling compounds. Journal of Experimental Marine Biology and Ecology, 190(1), pp.61-77.

[14]Bhakuni, D.S. and Rawat, D.S., 2005. Bioactive metabolites of marine algae, fungi and bacteria. Bioactive marine natural products, pp.1-25. 
[15]Řezanka, T. and Dembitsky, V.M., 2001. $\gamma$-Lactones from the soft corals Sarcophyton trocheliophorum and Lithophyton arboreum. Tetrahedron,57(41), pp.8743-8749.

[16]Van Alstyne, K.L., Wylie, C.R. and Paul, V.J., 1994. Antipredator defenses in tropical Pacific soft corals (Coelenterata: Alcyonacea) II. The relative importance of chemical and structural defenses in three species of Sinularia.Journal of Experimental Marine Biology and Ecology, 178(1), pp.17-34.

[17]Sammarco, P.W., Coll, J.C., La Barre, S. and Willis, B., 1983. Competitive strategies of soft corals (Coelenterata: Octocorallia): allelopathic effects on selected scleractinian corals. Coral Reefs, 1(3), pp.173-178.

[18]La Barre, S.C., Coll, J.C. and Sammarco, P.W., 1986. Defensive strategies of soft corals (Coelenterata: Octocorallia) of the Great Barrier Reef. II. The relationship between toxicity and feeding deterrence. The Biological Bulletin,171(3), pp.565-576.

[19]Coll, J.C., Price, I.R., König, G.M. and Bowden, B.F., 1987. Algal overgrowth of alcyonacean soft corals. Marine Biology, 96(1), pp.129-135.

[20]Coll, J.C., Bowden, B.F., Tapiolas, D.M., Willis, R.H., Djura, P., Streamer, M. and Trott, L., 1985. Studies of Australian soft corals-XXXV: The terpenoid chemistry of soft corals and its implications. Tetrahedron, 41(6), pp.1085-1092.

[21]Sammarco, P.W. and Coll, J.C., 1992. Chemical adaptations in the Octocorallia: evolutionary considerations. Marine Ecology-Progress Series,88, pp.93-93.

[22]Mayer, A., Rodríguez, A.D., Taglialatela-Scafati, O. and Fusetani, N., 2013. Marine pharmacology in 2009-2011: Marine compounds with antibacterial, antidiabetic, antifungal, antiinflammatory, antiprotozoal, antituberculosis, and antiviral activities; affecting the immune and nervous systems, and other miscellaneous mechanisms of action. Marine drugs, 11(7), pp.2510-2573.

[23]Tun, K., Ming, C.L., Yeemin, T., Phongsuwan, N., Amri, A.Y., Ho, N., Sour, K., Van Long, N., Nanola, C., Lane, D. and Tuti, Y., 2008. Status of coral reefs in Southeast Asia. Status of coral reefs of the world, pp.131-144.

[24]Soares, G.M.S., Figueiredo, L.C., Faveri, M., Cortelli, S.C., Duarte, P.M. and Feres, M., 2012. Mechanisms of action of systemic antibiotics used in periodontal treatment and mechanisms of bacterial resistance to these drugs.Journal of applied oral science, 20(3), pp.295-309.

[25]Gomaa, M.N., Soliman, K., Ayesh, A., Abd El-Wahed, A., Hamza, Z., Mansour, H.M., Khalifa, S.A., Mohd Ali, H.B. and El-Seedi, H.R., 2016. Antibacterial effect of the red sea soft coral Sarcophyton trocheliophorum.Natural product research, 30(6), pp.729-734.

[26]Zubair, M.S., Al-Footy, K.O., Ayyad, S.E.N., Al-Lihaibi, S.S. and Alarif, W.M., 2016. A review of steroids from Sarcophyton species. Natural product research, 30(8), pp.869-879.

[27]Temraz, T.A., Houssen, W.E., Jaspars, M., Woolley, D.R., Wease, K.N., Davies, S.N. and Scott, R.H., 2006. A pyridinium derivative from Red Sea soft corals inhibited voltage-activated potassium conductances and increased excitability of rat cultured sensory neurones. BMC pharmacology, 6(1), p.10.

[28]Badria, F.A., Guirguis, A.N., Perovic, S., Steffen, R., Müller, W.E. and Schröder, H.C., 1998. Sarcophytolide: A new neuroprotective compound from the soft coral Sarcophyton glaucum. Toxicology, 131(2), pp.133-143. 
[29]Sawant, S., Youssef, D., Mayer, A., Sylvester, P., Wali, V., Arant, M. and El Sayed, K., 2006. Anticancer and anti-inflammatory sulfur-containing semisynthetic derivatives of sarcophine. Chemical and pharmaceutical bulletin, 54(8), pp.1119-1123.

[30]Liang, L.F. and Guo, Y.W., 2013. Terpenes from the soft corals of the genus sarcophyton: chemistry and biological activities. Chemistry \& biodiversity,10(12), pp.2161-2196.

[31]Putra, M.Y., Murniasih, T., Swasono, R.T., Wibowo, J.T., Saputri, A.N.C., Widhiana, M.R. and Arlyza, I.S., 2016. Secondary metabolites and their biological activities in Indonesian soft coral of the genus Lobophytum. Asian Pacific Journal of Tropical Biomedicine.

[32]Zhao, H.Y., Shao, C.L., Li, Z.Y., Han, L., Cao, F. and Wang, C.Y., 2013. Bioactive pregnane steroids from a South China Sea gorgonian Carijoa sp.Molecules, 18(3), pp.3458-3466.

[33]Kapustina, I.I., Kalinovskii, A.I., Dmitrenok, P.S., Kuz'mich, A.S., Nedashkovskaya, O.I. and Grebnev, B.B., 2014. Diterpenoids and Other Metabolites from the Vietnamese Gorgonians Lophogorgia sp. and Junceella sp. Chemistry of Natural Compounds, 50(6), pp.1140-1142.

[34]Kumar, P., Selvi, S.S. and Govindaraju, M., 2012. In vitro anti-biofilm and anti-bacterial activity of Junceella juncea for its biomedical application. Asian Pacific journal of tropical biomedicine, 2(12), pp.930-935. 